\title{
Terrorist groups in Syria and Libya: a study of regional policies
}

\section{groups in Syria and Libya}

\author{
Osama Mahmoud Mohamed Abd Elgawad \\ Cairo University, Cairo, Egypt
}

\begin{abstract}
Purpose - This study is not intended to be a prescriptive blueprint for any nation or region to fight terrorism, but rather it aims to analyze the development of policies supporting terrorism and their impact on regional as well as international relations. It is an examination of relevant facts, which might hopefully benefit policy makers and practitioners who diligently work on reducing or eliminating terrorist activities.

Design/methodology/approach - In order to achieve the objectives of the paper and in light of the pool of the available literature and data, the study adopts the system-analysis method in analyzing the impact of policies supporting terrorism and the countermeasures to apply based on the inputs, outputs and conversions associated with the phenomenon of terrorism.

Findings - Policies supporting terrorism differ from a state to another starting from providing safe haven to terrorist groups to providing direct finance and armaments to directly intervening militarily in a targeting country. Or deter such policies. This raised the concerns of many States in the region regarding the domination tendency of Turkey and called for a firm and pragmatic international, regional and Arab stand beyond verbal condemnation to deter Turkey from pursuing such policies.

Originality/value - The importance of the academic study stems from the importance of addressing one of the central issues in the field of regional and international relations, which is the policies some states adopt to support terrorism, not only by financing terrorism but also by incubating terrorism. Most studies on terrorism focus on the concept and situations and not on policies that support terrorism and their impact on regional and international relations and the means of encountering terrorism.
\end{abstract}

Keywords Terrorism, Turkey, Terrorism support, Terrorism sponsorship

Paper type Research paper

\section{Introduction}

The growing phenomenon of terrorism in the world is one of the most serious forms of security threats states encounter because they target an important part; the security, stability and future of their societies, especially if the terrorist act combines the ambitions and objectives of external forces that do not want to use their direct tools but rely on engines to create crises within the target states either by exploiting prevailing borders or political disputes or in other times tearing apart the social fabric within the target country. External forces may even encourage one terrorist group to turn against another group if such group does not serve their objectives. External forces may also use terrorist groups to topple governments that hinder their interests in the area. Meanwhile, terrorism is borderless and may even impact the states that nurture it. Therefore, the confrontation of terrorism and terrorist acts has become a manifestation of the modern world and contemporary life.

The international reality witnesses a period of conflict over concepts and general confusion about what is happening in this world, from disturbances, skirmishes, dialogues and armed and unarmed conflicts. The world and states have not yet agreed over a uniform concept of terrorism simply because their interests differ. Some states have certain interests

(C) Osama Mahmoud Mohamed Abd Elgawad. Published in Journal of Humanities and Applied Social Sciences. Published by Emerald Publishing Limited. This article is published under the Creative Commons Attribution (CC BY 4.0) licence. Anyone may reproduce, distribute, translate and create derivative works of this article (for both commercial and non-commercial purposes), subject to full attribution to the original publication and authors. The full terms of this licence may be seen at http:// creativecommons.org/licences/by/4.0/legalcode.

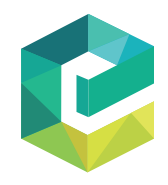

Journal of Humanities and Applied Social Sciences Vol. 4 No. 5,2022 pp. $457-468$ 2632-279X DOI 10.1108/JHASS-02-2021-0032 
JHASS 4,5

458 that embrace such concept and policy. Israel has its concept toward terrorism, and the Palestinians have their concept as well toward terrorism (El-Said, 2015).

Despite the concern of international charters for the maintenance of international peace, now we are living in an international community in which each country develops a concept of terrorism that fits its common and potential interests; the researcher has tried very hard to select the issue that is the basic concern of the international community and the world as a whole.

Therefore, research attempts to discuss the patterns and determinants of State support for non-State terrorist groups and its impact on the international and regional order:

What are the patterns and determinants of the policies supporting terrorism and the impact of such policies on the international and regional order?

This question raises other sub-questions:

(1) What are the policies that support terrorism and how have they evolved?

(2) What are the factors and determinants of the policies that support terrorism (strategic, military, security, economic, political and ideological)?

(3) What mechanisms has Turkey used to support terrorism?

The study aims to analyze the development of policies supporting terrorism and their trends in international relations, clarify the impact of those policies on national, regional and global security, the mechanisms of international and regional confrontation against the policies that support terrorism by studying and analyzing the concept of policies supporting terrorism in accordance with the mottos of international organizations and bodies, the classification of the community of the countries supporting terrorism, the objectives of those states, how to contain them, how to deal with those states that carry out those policies, what are the mechanisms adopted by the international community to address such issue and the effectiveness of such mechanisms in addressing these policies.

The study follows the policies in support of terrorism with a focus on the state of Turkey, which aspires to resurrect the Ottoman State and the caliphate system as well as playing a distinct regional role. To realize these objectives, Turkey shelters terrorist groups and organizations and adopts policies that support these organizations to serve its interests and assist in the collapse of other countries (Abu Amud, 2015).

The timeframe of the research covers the period from 2011 up to the time this research has been prepared. The reasons of choosing this period are due to the fact that these years witnessed the beginning of the Syrian and Libyan crisis and the Turkish role in supporting terrorist organizations.

\section{Literature review}

The problem of the study entails the need to take advantage of different levels and areas of previous studies and thus contribute in a more in-depth understanding of the problem and its different aspects. These studies can be grouped into two main axes:

First Axis: Literature on policies that support terrorism adopted by States and terrorist groups in terms of their patterns, determinants and perspectives, as well as terrorism in general:

Studies in that area dealt with policies that support terrorism, non-State terrorists and violent groups in terms of their patterns, mechanisms, causes, motives, interpretations, effects and breakdowns, as well as different interpretations of the concept of terrorism, whether directly through studies of terrorism or other analytical angles, such as external interventions in conflicts and internal and civil wars, symmetric or asymmetric war studies, hybrid alliance 
studies, etc., as well as the motives that led to the growing phenomenon of terrorism among those who assert that the nutrition of international competition and conflict has helped to feed international rivalries and conflict. The growth of the phenomenon of terrorism among those who claim that terrorism is a natural phenomenon that can appear in any society linked to various factors including the political, economic, social, religious and ideological environment needs to be defined in a way that clarifies its components and characteristics as different interpretations of the concept of terrorism lack a uniform concept that resulted in the emergence of policies supporting terrorism (Schaeffer, 2010; San-Akca, 2016; Proulx, 2012; Meconaghy, 2017; Collins, 2014; Berkowitz, 2017; Bailes and Aksan, 2013).

The second Axis: literature on studies of state-backed counter-terrorism strategies and their effectiveness, as well as Turkish and Qatari foreign policies in relation to their support of extremist groups during the study period:

Studies dealing with the mechanisms of counter terrorism, its effectiveness, international organization, the effectiveness of its mechanisms and its decisions in preventing the states sponsoring terrorism from supporting and financing terrorist organizations, as well as the global policies of international organizations and efforts in preventing the support and financing of terrorism and the assessment of their role such as the countries that support terrorism and incubate all terrorist groups that have entered Syria to undermine security and stability in Syria since the beginning of the crisis (Ridley, 2009; Francis, 2004; Bantekas, 2003; Abu Amud, 2015).

It can be said that previous studies, although important in the study of some aspects of the subject, they include a study and a direct examination of an international phenomenon that affects international relations; however, they did not address the policies that support terrorism, the ways of confronting them and the extent of their impact on international peace and security, Therefore, in this study, the researcher relies on human development reports issued by the United Nations and the reports of the US State Department on the state of terrorism in the world, on which the American policy relied on many of its international dealings as well as some studies made on Arab policies.

This means that there is a research gap in the contemporary literature concerning the lack of academic and applied studies on policies supporting terrorism, their responses in different environments and their impacts on the stability of international peace and security in the regional and global order.

\section{Methodology}

In the analysis of the impact of policies supporting terrorism and the means to counter them, the study relies on the system-analysis method based on the analysis of inputs, outputs and conversions associated with the phenomenon of terrorism.

This approach is based on the analysis of the international political system - the unit of analysis - and its sub-components, such as regional and international organizations and geographical regions, by examining the laws and rules governing international relations that define the shape and features of the international system, with the aim of reaching similar laws and models that show how these systems operate, identify sources and the manifestations of regularity, to finally reach general conclusions regarding the balance and imbalance factors that govern the development and transition of these major international systems and their sub-systems. This approach is based on the analysis of the international system and the Middle East system derived from one of the cases of the study, the State of Turkey, and is characterized by a dense pattern of relations and interactions that affect the country and the system as a whole. The study considers the existence of a number of interactions, which environmentally influence the system. These are represented in the 
JHASS 4,5

study of regional variables affecting the condition of the system and in particular the State of Turkey. These regional variables are represented in a number of issues; the most important of which are the policy issues of supporting and financing some terrorist entities, projects to divide the Arab world and abort Arab revolutions, all of which take place within the framework of the historical extrapolation of the map of the growth of terrorist entities and the context of those interactions.

Inputs include the political system according to the approach of systemic analysis of everything that the system receives from its environment.

Hence, the first entry includes the development of the system and the role of nongovernmental organizations and others including terrorist organizations, to name a few.

The second entry includes an increase in informal remittances in the international financial system.

The third entry includes the failure of a large number of countries in the Middle East and the Arab world, in particular, that caused ethnic, religious and sectarian conflicts, such as, Syria and Libya.

The fourth entry includes competition between major countries, particularly the United States and Russia, for the world's spheres of influence, particularly in the Middle East and the Arab world.

The fifth entry includes Turkey's role in supporting terrorism, which is contrary to all customs and rules of the United Nations, where one of the functions of the international system now is to confront terrorism, the newly existed phenomenon.

Second, conversions are the combination of activities and interactions of the system through which their input from resources, demands and support is transferred into outputs, i.e. decisions and policies framing the political system. Conversion is a sifting of inputs.

Third side outputs: Easton defined it as the system's set of decisions, and actions that had a mandatory status, under which the authoritarian allocation of values in society was made.

That is, how the countries of the international system have dealt with policies supporting terrorism by adopting protectionist policies and measures to counter those policies, such as the policies of the United States of America with ISIS, Russia and its role in maintaining the unity of Syria and NATO in resolving the Libyan issue and the role of Saudi Arabia in the state of Yemen.

\section{Study framework}

The study adopts the framework of a realistic school that focuses on the concept of "power in the analysis of international relations" and considers that the struggle over force is the main interpreter of international behavior, and therefore, the study adopts in its analysis of policies supporting terrorism the school of reality and its sayings.

In applying the case of the study, it is possible to identify three policies pursued by the State of Turkey in this context, the first policy is legitimizing terrorism by not describing terrorist elements as terrorists, treating them as "armed groups" or "opposition" elements and providing support to a number of forces of political Islam in Libya as they have the right to share power there.

The second policy is to present itself as a State that can negotiate with terrorists and is able to mediate for the release of the hostages they hold, which it has succeeded to perform on behalf of many States that refuse to negotiate directly with terrorist elements.

The third policy concerns its sponsorship of terrorist elements, as revealed by hosting of several leaders of the Muslim Brotherhood of Egypt. 


\section{The problem of defining terrorism and the policies supporting it}

Terrorism is one of the social concepts, and since, it is difficult to have an inclusive definition of this social conception in general, and we are facing one of the concepts around which there is no academic or political consensus about the development of the concept of terrorism that casts a shadow on the definition of the states sponsoring terrorism. However, we can depend on the definition of terrorism according to U.N. The General Assembly reported in 2005, "any action constitutes terrorism if it is intended to cause death or serious bodily harm to civilians or non-combatants with the purpose of intimidating a population or compelling a government or an international organization to do or abstain from doing any act” (Ekmekci, 2011).

We can say that terrorism commonly refers to acts of violence that target civilians in the pursuit of political or ideological aims.

It is usually difficult to define a country's counter-terrorism policies in comparison with the definition of counter-terrorism policies, given that terrorism is inherently politicized. What might be classified as terrorism in a State might not be seen as terrorism by another State based on political considerations. The State sponsorship of terrorism can range from a State directly supporting terrorist attacks, to less direct State involvement by tolerating particular terrorist groups, which base their activities in the territory of the State (Nyamuya, 2003).

US State Department designated the concept of "state sponsoring terrorism" that has repeatedly supported acts of international terrorism. The forms of support by States to terrorist organizations are varying.

As there is no specific definition of States supporting terrorism, they can range from states directly supporting terrorist attacks, to less directly by tolerating particular terrorist groups, which base their activities in the State's territory.

The traditional approach in the field of international relations is to treat terrorist organizations as "non-governmental" actors in international relations. Recently, this approach has changed since most terrorist organizations have become supported or exploited by some States. Rather, States have taken them to counter the growing threats to national security in an era of destructive wars. Recently, States tend to support foreign terrorist organizations that operate against their current enemies. State supporting terrorism remains the most serious and important aspects of terrorism. However, the identity and nature of the State that sponsors terrorism has changed in recent years. Although all governments have condemned terrorism rhetorically, many States are still providing valuable support to terrorist organizations at one time or another, and States' sponsorship of terrorism, though not as widespread as in previous decades, is still continuing. A complex phenomenon that our government has not yet adequately addressed, despite the threat it continuously pose to our national security (Ekmekci, 2011).

Since 1979, US State Department annually publishes its list of the countries considered to be sponsoring terrorism. Various countries have been included in the list, but most of the countries have been removed since the publication of the first list. In order for a country to end up on this list, the US State Department of State must provide evidence that the country it wants to designate as a state supporting terrorism has repeatedly supported terrorist groups and terrorist acts.

For listing a country on the list of terrorism supporting, the Secretary of State has to prove that the government has provided continuous support for terrorism. So State sponsoring terrorism must have helped a terrorist organization in any way, either financially, with weapons, providing sanctuary or even if the government is aware of the activities of the terrorist organizations (Areström, 2020).

Why did countries support terrorist organizations? There are many motives for States to support foreign terrorist organizations (Ekmekci, 2011).
Terrorist groups in Syria and Libya 
JHASS 4,5

462

Ideology: As in the case of Cuba's support for the Revolutionary Armed forces of Marx. Religion: as in the case of Iran's support for Shia Hezbollah. Internal/Electoral Concerns: as in the case of the early Indian support for the Tamil Tigers. These are among the factors that motivate a State to support a terrorist organization. However, the national security is the country's most common motive for supporting terrorism. In almost all major cases of the States supporting terrorism (such as Syrian and Greek support for the PKK, Iranian and Iraqi support for Hamas, Iranian support for Hezbollah, Iraqi and American support for the American organization MK, American support for the Cuban Kuru or Pakistani support for several armed and terrorist organizations.

Ideology: As in the case of Cuba's support for the Revolutionary Armed forces of Marx.

Religion: as in the case of Iran's support for Shia Hezbollah.

Internal/Electoral Concerns: as in the case of the early Indian support for the Tamil Tigers.

However, the national security is the country's most common motive for supporting terrorism. In all of these cases, States' support for terrorist organizations has been driven by the desire to weaken an enemy by using agents and/or using such support as bargaining chips against their enemies since the advances in military technology have made modern warfare extremely costly and destructive.

According to US law, support includes "the repeated use of any part of the country's territory as a haven for terrorists whether the government explicitly consented to, knowingly, allows, tolerates, or ignores such use of its territory,". It is important to make clear that the State's sponsorship of terrorism is distinct from the phenomenon that is often called state terrorism. The latter include the repressive acts used by agents of the State to suppress its citizens, such as the "dirty war" that occurred in Argentina in late 1970s, instead of treating care as a classification of "everything or nothing".

Policies supporting terrorism started from "incapacity", which means that the State does not have the capacity to assist or obstruct the terrorist organization operating within its territory, and "direct surveillance", which means that the State exercises full control over the organization, including ideology and operations (Reeves, 2011).

So, we can classify all forms of support provided to terrorist organizations into four categories: (Reeves, 2011)

Incapacity: a State may unwillingly support a terrorist organization simply because it does not completely control its territory. Such support is characterized, as "Incapacity". The classic example of this is Lebanon in the 1970s. Rocked with civil war and constant meddling by Syria, Lebanon, the government, to the extent it actually existed, was unable to prevent various Palestinian terrorist groups from establishing bases of operation within its territory.

Toleration: becomes when the State has the capacity to curb the terrorist organization, but for different reasons, it chooses not. A major example of tolerance is the Liberation Tigers of Tamil Eelam (LTTE). The LTTE's goal is to "establish an independent state encompassing ethnic Tamil areas of Sri Lanka”.

Support: when a State takes action that benefits a terrorist organization and begins to provide concrete forms of assistance.

Sponsorship: an excellent example of "Sponsorship" is the relationship between Pakistan and Lashkar-e-Tayyiba (LT). Formed in the early 1990s, LT's stated goal was to "liberate Kashmir from Indian control and establish an Islamic state there." However, recent actions indicate that the group is seeking to expand the Islamic State in India. Today, LT is considered one of the most effective jihadists. 
Direct control: the progress of the relationship between Iran and Hezbollah is the clearest example of "direct control." The origins of Hezbollah date back to the Iranian "Islamic Revolution" in 1979. Shortly, after the seizure of power, the regime chose it with a large number of mature Shia to continue the revolution.

How do States support terrorist organizations? (Reeves, 2011)

We can classify the forms of support provided to a terrorist organization into four categories: financing, government services, logistics and safe havens.

Financing: all financial support provided by the State to the terrorist organization. For example, a State can financially support a terrorist organization by allowing the group to fundraise within its borders or transfer millions of dollars directly into the group's coffers on the high end.

Government services: includes services that a terrorist organization might need from the State. This can be of a wide range including passports and other diplomatic services, intelligence gathering or political support in the public arena.

Logistics: includes all forms of logistical support. The most obvious example is weaponry. However, other instances might include facilitating the transport of people via buses or planes to terrorist training camps.

Safe haven: the most important form of support that a State can offer is a safe haven. A State allowing terrorists to freely exist within its borders offers the organization the ability to focus its efforts on activities beyond mere survival, ultimately making the organization more dangerous.

Finally, the State may combine more than one mechanism to support a terrorist group at more than one level. This is demonstrating in the Turkish support of terrorist organizations.

\section{Turkish policies in support of terrorism}

In recent years, Turkey believes in earning more influence in the Middle East for many reasons (Lindenstrauss and Kivam, 2014).

First: Turkey is no longer satisfied with the current situation but is seeking a greater place and role in the region.

Second: the new Ottoman tendencies in Turkey: its desire to reaffirm its influence in the territories that were before part of the Ottoman Empire.

Third: develop the Turkish economy and meet the growing energy needs at least by strengthening its power trade with Middle Eastern countries.

Islamism is the glue that brings together the Qatari-Turkish. Erdoğan's government has a long history with Muslim brotherhood, which the Turkish leader began to embrace publicly after gaining a large majority in Turkey's 2007 election. Inside, Erdogan supported Islam and expanded religious education and state-run propaganda schools to institutionalize sectarian domination, armed Turkish media to give Islamic propaganda and attack pro-secularism opposition. In 2014, Qatar and Turkey supported the general national conference, which is based in Tripoli (Gauthier-Villars and Malsin, 2019).

\subsection{Turkish support of armed opposition in Libya}

Erdoğan government has strong ties with Libyan-armed militias. Its support ranges from coordination to providing military weapons and financial support. Turkish had deep ties with Brotherhood groups, Misrata Brigades, the Libyan guerrilla group and other militias which fight against the Libyan National Army (Abul Ela, 2020).

Turkey is targeting to achieve many gains, some of which are related to Libya's potentials, location and the resources it has, some of which are related to the comparative advantage that 
JHASS

4,5

\section{4}

the Turkish government sees for itself there, So Erdoğan does not treat Al-Sarraj as a normal ally but rather treats al-Wefaq as his only chance not to meet the same fate he has encountered in Syria. It is therefore a battle of fate for Erdoğan to resolve the issue of Turkish influence and presence in Libya and North Africa, and in doing so, he is not content with various forms of economic and political support but uses several forms of military support ranging from support to proxy warfare to direct warfare (Burweila, 2019).

There are many reasons for Turkey's intervention in Libya; the first and the most important ones.

(1) Securing energy sources, where Turkey imports $95 \%$ of its oil needs from Libya and seeks to play the role of distributor of Libyan oil. Libya has fifth Arab position in the oil reserves, with $3.76 \%$ of the global reserves, other raw materials and untapped energy sources that open the door to global prominence for its owners.

(2) The Egyptian, Israeli and Cyprus talks represent a threat to Turkey's role in the region. The Security and Maritime Agreement of November 2019 was therefore the first agreement that Turkey signed with the Libyan side to place a hand in the Mediterranean and protect its maritime rights.

\subsubsection{Forms of Turkish support to the Libyan armed opposition.}

(1) Military support

Turkey supported El Siraj with military forces and expanded its support after the Government of Siraj had requested broad intervention from the Turkish Parliament.

(2) Weapons supplies and operational support

Turkey uses the sea and air routes to deliver armament supplies to Libya. It has allocated a substantial budget for the development of domestic military production in the construction of advanced fast ships and submarines, the construction of air military power and the expansion of the drone fleet. The Turkish ship, Amazon, arrived at the port of Tripoli in May 2019, carrying 40 military vehicles for armed militias.

(3) Reemployment of Syrian mercenaries in Libya

Erdogan and his government have strong ties with armed militias, mainly Muslim brotherhood groups and Misrata brigades. Turkey recruited militias for proxy war in Libya. Most estimates suggest that Ankara sent many Syrian fighters to Libya in exchange for promises of monthly salaries, services and housing, although international and national laws in Libya prohibit their recruitment and their use in armed or terrorist acts.

6.1.2 Repercussions of the Turkish intervention in Libya. Turning Libya to a terrorist hotbed by transferring Syrian terrorist to Libya means establishing a zone for them on Libyan territory, in which case it would threaten the countries of North Africa, primarily Egypt.

6.1.3 Regional and international reactions to Turkish support for Libyan armed opposition. The Arab League condemned the Turkish military intervention in Libya as threatening the security and stability of the region. Egypt also denounced the Siraj Agreement with Turkey and mobilized international efforts to condemn it.

Turkey violated the United Nations resolution banning the armament of the Libyan army, which, in paragraph $13 \mathrm{~b}$ of resolution 2011, prohibits arming or training the Libyan army except by reference to the United Nations.

The European States condemned the Maritime Agreement as it violates international laws and sovereign rights. 
Turkey's presence in Syria dates back to 2011. Turkish support is based on the Justice and Development Party ideology, calling that secular regimes should be replaced by the "Islamic group" in the Middle East. However, Turkey's priorities have changed with the rise of SyrianKurdish autonomy, which Ankara considers a threat to its efforts to contain its separatist Kurdish insurgency (Stanicek, 2019).

Moreover, a report issued by US Treasury Department, confirmed that ISIS continues to rely on "logistical hubs" inside Turkey to finance it (Department of the Treasury Washington, D.C, 2021).

The reasons for Turkey's intervention in Syria were many, the first and the most important ones.

(1) The Syrian crisis is directly linked to its national security.

(2) The steady progress of the Kurdish political project on its southern border.

(3) The complexity of the Syrian situation on the ground suggests a possible defeat or a major retreat of the opposition, and the implications for Turkey, which could lead it to intervene with a view to attempt adjusting and balancing the situation.

\subsubsection{Forms of Turkish support to Syria armed groups.}

(1) Lobbying and diplomatic support for political reforms in Syria.

(2) Hosting Syrian opposition in Turkey.

(3) Ankara has been providing support to the Syrian opposition at several levels and dimensions, including media, political, logistical and even military, although this has not been publicly recognized.

\section{Conclusion}

From the previous analysis and results, we conclude that policies supporting terrorism differ from a state to another starting from "incapacity", which means that the State does not have the capacity to deter the terrorist organization operating within its borders, to "direct surveillance", which means that the state exercises full control over the organization, As evidenced, Turkey's efforts, which are against the norms of international law, require a coordinated response by the international community to force it to reconsider those policies. The international community should take a multifaceted approach involving its transatlantic Allies and regional partners to force Turkey to abandon those policies. The international community must impose sanctions on individuals and entities in Turkey that are involved in terrorism support and illicit finance. Moreover, a number of significant steps have been taken that reflect this concern. This includes the adoption of UN General Assembly CounterTerrorism Strategy in 2006. This milestone in the international initiatives to counter terrorism provides for a comprehensive response to terrorism at the national, regional and global level. However, the international community has been unable to apply this in the last few years in the face of terrorism as every country develops a special concept of terrorism that suits their national security. The followings are some recommendations to counter terrorism and dry up its source:

(1) Dissuading groups from resorting to terrorism or supporting it, by working on addressing the conditions that terrorists exploit. 
JHASS

4,5

\section{6}

(2) Using the platforms of international organizations to raise global awareness of the dangers of policies of the States that promote terrorism and should project a clear, principled and immutable message that terrorism is unacceptable.

(3) Revising terrorism related international laws and legislations and considering the need to develop a more specific definition for terrorism on the basis of which we can counter terrorism.

(4) International civil society must hold highly visible constructive dialogues among respected representatives from different religions to counter terrorist groups' portrayal of parts of the globe as being engaged in an epic struggle between good and evil, and to reinforce the fact that the killing of civilians is antithetical to all religions.

(5) Funding organizations direct international funding to promote religious and ethnic tolerance through education, and enlightened moderation as an alternative to militancy and extremism.

(6) Deterring States from supporting terrorist groups, by promoting United Nations system in countering those states.

The most effective means to counter policies supporting terrorism is the economic development. Economic development initiatives provide citizens, in poor and developing nations with the opportunity to improve their life, increase their incomes and achieve better healthcare.

\section{References}

Abul Ela, A.M. (2020), Turkish Military Intervention in Libya. His Pictures and Consequences on Terrorist Groups, Arab Center for Research and Studies, Cairo, available at: http://www.acrseg. org $/ 41453$.

Abu Amud, M.S. (2015), "Turkey and the dream of the production of the Ottoman Caliphate", International Politics Journal, No. 201, p. 45.

Areström, F. (2020), State-Sponsored Terrorism: the Case of Pakistan, Linnaeus University, available at: http:/www.divaportal.org/smash/get/diva2:1394958/FULLTEXT01. Pdf.

Bailes, J. and Aksan, C. (2013), Weapon of the Strong. Conversations on US State Terrorism/interviews by Cihan Aksan and Jon Bailes, Pluto Press, London, available at: https://www.tandfonline.com/ doi/abs/10.1080/17539153.2013.855385.

Bantekas, I. (2003), "The international law of terrorist financing”, American Journal of International Law, Cambridge, Vol. 97 No. 2, pp. 315-333, doi: 10.2307/3100109.

Berkowitz, J.M. (2017), "Delegating terror, and principal-agent based decision making in state sponsorship of terrorism", in International Interactions.

Burweila, A. (2019), Turkey's Support to Libya's Outlaw Militias and the Threat to Europe's Southern Flank, Research Institute for European and American Studies, available at: https:/www.rieas. gr/images/editorial/rieasayanew1.pdf.

Collins, S.D. (2014), "State- sponsored terrorism. In decline, yet still a potent threat", in Politics and Policy, Vol. 42, No. 1.

Department of the Treasury Washington, D.C. (2021), available at: https://www.turkeynow.news/ black-box/2021/01/27.

Ekmekci, F. (2011), Terrorism as War by Other Means: National Security and State Support for Terrorism, available at: $\mathrm{https}: /$ www.scielo.br/scielo.php?pid $=$ S0034-73292011000100008\&script $=$ sci_arttext.

El-Said, H. (2015), New Approaches to Countering Terrorism: Designing and Evaluating Counter Radicalization and De-Radicalization Programs, Palgrave Macmillan. 
Francis, D.R. (2004), The War Terror Money, Christian Science Monitor, Boston.

Gauthier-Villars, D. and Malsin, J (2019), In Libyan War, Turkey Takes Sides against Mideast Rival, the Wall Street Journal, available at: https://www.wsj.com/articles/in-libyan-war-turkey-takes-sidesagainst-mideast-rivals-11562065082.

Lindenstrauss, G.M. and Kıvam, S.K. (2014), Turkish-Hamas Relations: between Strategic Calculations and Ideological, Talabib, available at: https://strategicassessment.inss.org.il/wp-content/ uploads/antq/fe-2036312999.pdf.

Meconaghy, K. (2017), Terrorism and the State Intra-state Dynamics and the Response to Non-state Political Violence, Palgrave Macmillan (rethinking political violence), London.

Nyamuya, J. (2003), "War on the enemy: self defence and state sponsored terrorism", Melbourne Journal of International Law, available at: https://law.unimelb.

Proulx, V.-J. (2012), “Transnational terrorism and state accountability”, A New Theory of Prevention Oxford: Hart Monographs in Transnational and International, Law, Vol. 9.

Reeves, J.R. (2011), A New Typology for State Sponsored International Terrorism, Naval Postgraduate School Monterey, California.

Ridley, N. (2009), Combating the Financing of Terrorism, Emirates, Occasional Papers, 1st copy, Emirates.

San-Akca, B. (2016), "International support for nonstate armed groups", Oxford Bibliographies Online Datasets, available at: http:/www,oxfordbiographies.com/view//document/obo-9780199743292/ obo-9780199743292-0185.xml?rskey $=5$ huwsa\&result $=2 \& q=\% 22$ state + sponsored + terrorism $\% 22$ \#firstmath.

Schaeffer, C.M. (2010), State Sponsorship of Terrorism: A Comparison of Cuba's and Iran's Use of Terrorism to Export Ideological Revolutions, available at: http://mars.gmu.edu/handle/1920/ 6410 ? show $=$ full.

Stanicek, B. (2019), Turkey's Military Operation in Syria and its Impact on Relations with the EU, available at: https://www.europarl.europa.eu/EPRS/EPRS-Briefing-642284-Turkeys-militaryoperation-Syria-FINAL.pdf EPRS|European Parliamentary Research Service.

\section{Further reading}

Ahmed al - Qurani, Turkish Influence in the Libyan Crisis... Political and Security Implications, International Institute of Iranian Studies, available at: https://rasanah-iiis.org/wp-content/ uploads $/ 2021 / 01 / \%$ D8 $\%$ A7 $\%$ D9 $\% 84 \%$ D9 $\% 86 \%$ D9 $\% 81 \%$ D9 $\% 88 \%$ D8 $\%$ B0- $\%$ D8 $\%$ A7 $\%$ D9 $\% 84 \%$ D8 $\%$ AA $\%$ D8 $\%$ B1 $\%$ D9 $\% 83 \%$ D9 $\% 8$ A- $\%$ D9 $\% 81 \%$ D9 $\% 8$ A- $\%$ D8 $\%$ A7\% $\% 9 \% 84 \%$ D8\%A3\%D8\%B2\%D9\% 85\%D8\%A9- $\%$ D8 $\%$ A7 $\%$ D9 $\% 84 \%$ D9 $\% 84 \%$ D9 $\% 8$ A $\%$ D8 $\%$ A8 $\%$ D9\%8A $\%$ D8\% A9..- $\%$ D8\%A7\%D9\% 84\%D8\%AA $\%$ D8\% AF $\%$ D8\%A7\%D8\%B9\%D9\%8A $\% \mathrm{D} 8 \%$ A7 $\%$ D8 $\%$ AA- $\%$ D8 $\%$ A7 $\%$ D9 $\% 84 \%$ D8 $\%$ B3\%D9\%8A $\%$ D8 $\%$ A7 $\%$ D8 $\%$ B3 $\%$ D9 $\% 8$ A \%D8\%A9-\%D9\% 88\%D8\%A7\%D9\% 84\%D8\%A3\%D9\% 85\%D9\% 86\%D9\%8A \%D8\%A9. pdf (accessed 6 January 2021).

Al Hajj, S., External SES Determiners for Syri, March,2016, Adark Centre for Studies and Consulting, available at: https://idraksy.net/wp-content/uploads/2016/02/turkey-foriegn-policy-syria.pdf.

Alhami, M.Y. (2002), International Terrorism between Sharia and Law and the Distinction between Terrorism and Legitimate Struggle, Dept of law, College of Administrative Sciences, King Saudi University, Riyadh.

Alawi, M. (2015), Arab Security Threats Complex Map, Vol. 50, No. 201, SIS, Cairo.

Al Bustani, J.M., Elsayed Mohamed, M. and Nabawy Mostafa, M. (2020), "Turkish intervention in Libya and its impact on Egyptian National Security", May 1, Arab Centre for Research and Studies, available at: http://www.acrseg.org/41600.

Arab Center for Research and Policy Studies (2020), Turkey's Growing Role in Libya: Motives, Background and Responses, Al-Dayaen, Qatar, available at: https://www.dohainstitute.org/en/

Terrorist
groups in Syria
and Libya

\section{$-$}


JHASS 4,5

Lists/ACRPS-PDFDocumentLibrary/The-Growing-Turkish-Role-in-Libya-Background-andResponses.pdf.

Arkan, I. and Mustafa, J.F., "Determinants of the Turkish role in Libya and its international repercussions", Anbar University, Faculty of Law and Political Science, Department of Political Science, First Issue 2020, Vol. X, available at: https://www.researchgate.net/publication/ 342513788_mhddat_aldwr_altrky_fy_lybya_wtdayath_aldwlyt.

Erdemir, A. and Koduvayur, V. (2019), Brothers in Arms. The Consolidation of the Turkey-Qatar Axis, FDD PRESS, Washington, DC.

Kissinger, H. (2014), World Order, 1st ed., Vol. 9, Penguin Press.

Mendelsohn, B. (2016), The Al-Qaeda Franchise: the Expansion of al-Qaeda and its Consequences, Oxford University Press.

Office of the United Nations High Commissioner for Human Rights (2020), available at: https://www. ohchr.org/documents/publications/factsheet32en.pdf.

Peers, S. (2003), EU Responses to Terrorism, Cambridge University Press, The International and Comparative Law Quarterly, Cambridge, available at: https://www.jstor.org/stable/3663215.

United Nations General Assembly (2005a), available at: https:/www.un.org/en/development/desa/ population/migration/generalassembly/docs/globalcompact/A_RES_60_1.pdf.

United Nations General Assembly (2005b), In Larger Freedom: Towards Development, Security and Human Rights for All, available at: https://www.ohchr.org/Documents/Publications/A.59.2005. Add.3.pd.

United Nations General Assembly (2006), Sixtieth Session Agenda Items 46 and 120, available at: https://www.un.org/en/ga/search/view_doc.asp?symbol=A/60/825.

Walker, C. (1992), The Prevention of Terrorism in British Law, 2nd ed., Manchester University Press.

\section{Corresponding author}

Osama Mahmoud Mohamed Abd Elgawad can be contacted at: osamaabdelgawad4@gmail.com

For instructions on how to order reprints of this article, please visit our website:

www.emeraldgrouppublishing.com/licensing/reprints.htm

Or contact us for further details: permissions@emeraldinsight.com 